\title{
THE STUDENTS' DIFFICULTIES IN LEARNING READING COMPREHENSION USING COOPERATIVE LEARNING THROUGH JEOPARDY GAME
}

\author{
Susi Suryani $^{1}$, Evie Kareviati ${ }^{2}$ \\ IKIP Siliwangi \\ ${ }^{1}$ susisuryani@ student.ikipsiliwangi.ac.id, ${ }^{2}$ ekareviati@gmail.com
}

\begin{abstract}
English is an international language learned in Indonesia. One of the difficulties of student learning is when learning to read. They tend to read without knowing the meaning of the text they are reading. On this occasion the researcher tried to teach comprehension reading using cooperative learning through jeopardy games to increase students' interest and ability in learning reading comprehension. In addition, researchers also want to find out what difficulties students face when learning to use jeopardy game through this jeopardy game. This research was conducted on students of class VIII E Semester 1 SMPN 1 Cililin which consists of 36 students. This research was conducted using the Classroom Action Research (CAR). From the results of the pretest and posttest, there were 20 pretest results from 36 students or $56 \%$ who succeeded in reaching the minimal completeness criteria. Whereas in the posttest there was an increase to 28 out of 36 students or $78,85 \%$ who successfully reached the minimal completeness criteria. Then it can be concluded the use of games in learning increases the ability of students in reading comprehension. However, there are some students who still find it difficult to learn to use this method because their vocabulary mastery is still lacking.
\end{abstract}

Keywords: Reading Comprehension, Cooperative Learning, Jeopardy Game

\section{INTRODUCTION}

Language is a tool for communication. English is an international language learned in Indonesia. English is in the curriculum of learning in Indonesia. According to Afriansyah (2019) to Educational curriculum is all the processes of activities that are planned and carried out in earnest and continuous guidance on the situation of teaching and learning in schools. The development of the English curriculum in Indonesia is very varied, as evidenced by the change of curriculum since the beginning of the emergence of the English curriculum in 1975 until now. In addition, English subjects are one of the important subjects because English is always present in the National Examination both in elementary schools, junior high schools, and high schools. Therefore it is very important for students to understand English properly and correctly.

There are four skills we must master in learning English including listening, speaking, reading and writing. According to Harmer (2007) as cited Kamban, Muhammad Dahlan (2019) States that reading and writing are productive skills because they involve language production. But on the other hand speaking and writing is also often referred to as a receptive skill because it involves receiving messages.

According to Lorange (2014) Parmawati (2018) as cited Syarief et al. (2020) Reading is an activity where we get information such as from pictures, patterns, shapes, and rhythms based on an understanding that is recognized through repeated meetings and then makes the shape remembered; which is made in reading exceeds the meaning that arises from the interpretation 
of written language. Reading is an activity informed by the apprehension of images, shapes, patterns, and rhythms, which come to be recognized through repeated encounters and remembered forms; the meanings that are made in reading are in excess of the meanings that arise from the interpretation of written language (Lorange, 2014: 30) in Parmawati (2018). Reading is one of the important skills in learning English. Because by reading we can get the information we need besides learning to read can also help to increase student vocabulary. Because by reading English text students become curious and want to know the meaning of the words they are reading. That way students can improve their reading skills while increasing their vocabulary.

Reading can be done by students easily, but most of the students find it difficult to understand the contents of the text they are reading, especially in understanding English-language text. According to Syamsu \& Agussalim, n.d.(2019) Reading comprehension is the ability to process and understand the contents of texts, this is the ability of individuals where they can process and get information from what they read. According to Efendy \& Sulistyo (2019) However, the process of comprehending English texts is more complex regarding its importance in the education context. So, reading comprehension is an important part of learning English, to understand every text that students read.

According to Mulyono (1999:11) as cited Kalimantan (2019) difficulties learning can be classified into 2 groups namely: developmental learning disabilities and academic learning disabilities. The facts contained in the field besides the difficulty in understanding the contents of the text they read, students also tend to be lazy and bored when learning English because they feel English is difficult. Therefore the research wants to find out ways to make students learn English with fun and not make students bored. On this occasion the authors apply the use of games for student learning, and want to find out what difficulties students face when learning to use this game.

The use of games in the learning process is one of the pedagogical practices of this technique which is useful for excellence in learning techniques, is responsive to various types of student motivation, and makes students closer to each other (Sanders et al., 2020). Basically it can facilitate various learning outcomes.

The game used by the research is Jeopardy Game. Jeopardy game is a game that is played individually or in groups. Jeopardy has a simple rule structure, so it can be played anywhere. Jeopardy games will be fair and fun for all. For teachers, this will be very helpful, because with a little preparation, Jeopardy can transform a traditional classroom into a fun play period. Further, the Jeopardy game is a game that has been used in a variety of student learning in various contexts that are played with discipline, among others in certain contexts, this game is usually designed to facilitate knowledge in various fields or content from easy to difficult to use techniques motivation. Therefore this game is one of the games that are suitable for use in the learning process (Sanders et al., 2020) .

Cooperative learning is a learning model used by the research. According to Tran et al., (2019) Cooperative learning, is one type of teaching methods. In this teaching method the teacher divides students into small groups and then the students work together and help each other to learn the material provided. Cooperative learning will applied in this study is the STAD (student team achievement division) method. STAD is one of the methods used in 2013 curriculum. STAD addresses this challenge by by arranging an activity that can make students and each member in the group work together and master the goals that have been set based on individual tests and group scores (Awada et al., 2019). In every class there must be students who tend to be smart, moderate, and less, by using the STAD method, the teacher can divide students into groups, in each group consisting of students who are smart, moderate, and less. Then the smart 
student can help other students in the learning session. They will tend to share because they are in one group.

\section{METHOD}

In this study researchers used classroom action research. According to Fitriani \& Wahyuni (2020) Classroom Action Research is an applied research that aims to improve and improve the quality of the learning process and the quality of student learning based on the results of evaluations or reflections conducted by the teacher, which includes observation and evaluation. The Classroom Action Research Cycle (CAR) uses four steps (1) planning, (2) implementation, (3) observing, and (4) evaluating or reflecting. This research is a teacher's effort to improve teaching and learning in the classroom. It is hoped that this research will bring change and develop classroom practice.

This research was conducted at SMPN 1 Cililin, the subjects in this study were class VIII semester 1 with a total of 36 students, consisting of 15 men and 21 women. To retrieve data the students were given a pre-test before learning to read comprehension using cooperative learning through jeopardy games, the number of questions given during the pre-test was 20 questions. At the next stage of the meeting students are given a reading comprehension using cooperative learning through jeopardy game. Jeopardy game is implemented in the classroom by using projector media, with this media it is hoped that students will also become more interested in participating in game sessions. The text given to students is text and the text contained in the teacher and student handbook is the When English Ring a Bell. The use of this book aims to keep this research following the syllabus and student learning material can still be achieved. Other than that this study also follows the time allocation given by the subject teacher time for one meeting is $2 \times 40$ minutes. While many meetings were conducted for this study as many as 6 meetings including Pre-test and Post-Test. A post-test is given at the end of the meeting, after all learning treatments are finished.

While the way to play this jeopardy game is played by displaying points if they have chosen a value or point the teacher will reverse or show questions related to the text they read before there are questions. So students will initially choose the points they get, the greater the point value, the more difficult the question, the smaller the point value, the easier the question. However, there is a time limit for them to answer this question, if they cannot answer, the points they have obtained previously will be deducted.

\section{RESULTS AND DISCUSSION}

\section{Results}

Because English is the second language in Indonesia, and most of the students do not understand English because the environment is not very supportive to improve their English skills. Then the results in the field show students find it difficult when learning English. Because they feel English is difficult, they tend to be lazy when they have to take English lessons. While learning to understand text is one of the important skills in learning. Therefore the researcher tries to teach English using jeopardy game through jeopardy game, and wants to know what difficulties students face when learning to use this method.

Table 1.

The Schedule of Activity 


\begin{tabular}{|c|c|c|}
\hline Meeting & Topic & Activity \\
\hline 1. & Pretest & Give student pre-test reading \\
\hline 2. & $\begin{array}{c}\text { Treatment } \\
\text { (Cycle) }\end{array}$ & $\begin{array}{l}\text { Explain what jeopardy game is and how to play, as } \\
\text { well as learning objectives, then divide students } \\
\text { into groups division of students is done by the } \\
\text { STAD method and try to play the game. }\end{array}$ \\
\hline 3. & $\begin{array}{c}\text { Treatment } \\
\text { (Cycle) }\end{array}$ & $\begin{array}{l}\text { Give students the text that has been prepared, then } \\
\text { students sit in accordance with the group that has } \\
\text { been prepared before. Re-apply jeopardy game to } \\
\text { learn reading comprehension. }\end{array}$ \\
\hline 4. & $\begin{array}{c}\text { Treatment } \\
\text { (Cycle) }\end{array}$ & $\begin{array}{l}\text { Give students the new text, then students sit in } \\
\text { accordance with the group that has been prepared } \\
\text { before. Re-apply jeopardy game to learn reading } \\
\text { comprehension. }\end{array}$ \\
\hline 5. & $\begin{array}{c}\text { Treatment } \\
\text { (Cycle) }\end{array}$ & $\begin{array}{l}\text { Give students the new text, then students sit in } \\
\text { accordance with the group that has been prepared } \\
\text { before. Re-apply jeopardy game to learn reading } \\
\text { comprehension. }\end{array}$ \\
\hline 6. & Post Test & Give student post-test reading \\
\hline
\end{tabular}

Previously minimal completeness criteria had been prepared to find out how far the ability of students, students who got a score of $\geq 70$ then fulfilled the minimal completeness criteria and included students who passed the pre-test. In this study, researchers used CAR, when conducting a pre-test researchers found 20 out of 36 students scored below the minimal completeness criteria. That means mastery of students' reading comprehension skills is still lacking, researchers try to find out the difficulties faced by students, during pre-test students find it difficult to focus, and so on. Then there must be improvements in improving the situation of learning in class in the next meeting to achieve the criteria for success.

The researcher tries to apply the teaching method of reading comprehension using cooperative learning through jeopardy games at the next meeting, to see whether the weaknesses of the students above can be overcome using this method, and to find out what difficulties students have when learning to use this jeopardy game.

Each group is given a text to read and understand first before the game process takes place. In cycle 1 the students were initially confused by how to play jeopardy games. But in cycle 2 they have begun to understand how to play this jeopardy game. In Cycle 3 and Cycle 4, students were very active when learning to read comprehension using cooperative learning through jeopardy games. Because this game is a group game and they work together to answer and get the highest point. They are very active to compete and become the best among the other groups.

For researchers the use of jeopardy game through jeopardy game is enough to make students active in learn reading comprehension, moreover the application of student teams achievement division divides students equally from the smart, the medium, and the less. They can help each other in answering questions.

After conducting treatment for 4 meetings the researchers conducted a pre-test. Pretest results show there is an increase in students who score $\geq 70$ to 28 of 36 students, an increase in the 
number of students who score above the minimal completeness criteria cannot reach the maximum. However, this research shows that the use of jeopardy games can increase students' interest in learning English and reading comprehension. While the difficulty of students in learning to use this jeopardy game is that some of them still do not understand a few words so they have to open a dictionary while this game uses a time limit, so that several times they cannot answer questions and their questions are taken over by other groups.

\section{Discussion}

This research was conducted in 6 meetings in one meeting with $2 \times 40$ minutes. The results of the study of the reading ability of eighth grade students in SMPN 1 Cililin increased. The increase included, among others, (1) increasing the average score, at the time of the pretest the number of students who reached minimal completeness criteria was as much as 20 of 36 students was equal to $56 \%$, while at posttest as many as 28 of 36 students managed to reach the minimal completeness criteria was equal to 78.85 thus there was a $28 \%$ increase. (2) Increased students' reading comprehension. It can be seen from how students become active learning in the classroom very well than when learning to use ordinary methods.

While the difficulties faced by students who still do not really understand English or whose vocabulary knowledge is still lacking. They tend to be less active during the game.

\section{CONCLUSION}

Based on the results of research conducted and discussions can be concluded teaching reading comprehension using cooperative learning through jeopardy games can improve students' learning abilities in learning English at SMPN 1 Cililin. The results of the pre-test and post-test scores prove that this method is able to improve students' reading comprehension skills. Besides that students also become more active, they can share and cooperate with group members.

While the difficulties students face when teaching methods using jeopardy games and cooperative learning are applied. Smart students tend to be more active during lessons, and students who have limitations in vocabulary must look up the meaning of words they don't understand in the dictionary, even though this actually also helps them to add to their vocabulary, but because this is a game there is a rule and time limit. Some groups cannot answer the question because it exceeds the time limit given to answer the question.

\section{ACKNOWLEDGMENTS}

I give my thanks to Allah SWT, because thanks to his blessings, thank God the researchers were given health, inspiration and ability so that I could finish this journal. This project is supported by IKIP Siliwangi Bandung, the researcher would like to thank Dra. Evie Kareviati, M.Pd for guiding, giving advice and supporting in completing this project. Thanks to the principal and teachers at SMPN 1 Cililin who have provided facilities for this research. Thanks to parents and friends who always support and pray so that researchers can complete this project. Hopefully this journal can be useful for readers and other researchers in the future.

\section{REFERENCES}

Afriansyah, H. (2019). Administrasi Kurikulum. Administrasi Kurikulum, Padang, 1-3. https://doi.org/10.17605/OSF.IO/Y6VXZ

Awada, G., Burston, J., \& Ghannage, R. (2019). Effect of student team achievement division through WebQuest on EFL students' argumentative writing skills and their instructors' perceptions. Computer Assisted Language Learning, O(0), 1-26. 
https://doi.org/10.1080/09588221.2018.1558254

Efendy, A. G., \& Sulistyo, G. H. (2019). Reading Strategy' s Failure to Deliver toward Reading Comprehension. 1034-1042.

Fitriani, S., \& Wahyuni, U. (2020). Pelatihan Lesson Study Dan Penulisan Laporan Penelitian Tindakan Kelas ( Ptk ) Bagi Guru Sekolah Menengah Kejuruan. 3(1), 136-144.

Kalimantan, J. (2019). Lamatsil @ Studi Literatur Kesulitan Siswa Studi Literature Kesulitan Siswa Smp / Mts Diponegoro Wuluhan Dalam Pembelajaran Mata Pelajaran Bahasa Inggris Lamatsil Imroatus Sholehah Program Studi Pendidikan IPA Jurusan Pendidikan MIPA Fakultas Keguruan Dan Ilmu Pendidikan Universitas Jember. April, 97-100.

Kamban, Muhammad Dahlan, F. (2019). Enhancing Reading Comprehension By Combining Paca and Vip Strategy At the Second Grade Senior High School. Celebes Education Review, 1(1), 26-33. https://doi.org/10.37541/cer.v1i1.56

Parmawati, A. (2018). The Study Correlation Between Reading Habit And Pronunciation Ability at the Second Grade Students of IKIP Siliwangi. Eltin Journal, Journal of English Language Teaching In Indonesia, 6(1), 46-52. https://doi.org/10.22460/eltin.v6i1.p46-52

Sanders, J. R., Arce-Trigatti, A., \& Arce, P. E. (2020). Promoting student problemidentification skills via a Jeopardy-inspired game within the Renaissance Foundry. Education for Chemical Engineers, 30, 49-59. https://doi.org/10.1016/j.ece.2019.10.001

Syamsu, T., \& Agussalim, H. (n.d.). Visual Imagery Strategy In Enchance Students 'Reading. $6(1), 1-4$.

Syarief, I. F., Apsari, Y., \& Dewi, A. N. K. (2020). The Use of Book Story in Teaching Reading Comprehension. PROJECT (Professional Journal of English Education), 3(2), 276. https://doi.org/10.22460/project.v3i2.p276-282

Tran, V. D., Nguyen, T. M. L., De, N. Van, Soryaly, C., \& Doan, M. N. (2019). Does cooperative learning may enhance the use of students' learning strategies? International Journal of Higher Education, 8(4), 79-88. https://doi.org/10.5430/ijhe.v8n4p79 